\title{
STUDI HYGIENE SANITASI DAN PEMERIKSAAN JUMLAH ANGKA KUMAN PADA PENJUAL CIMOL DI JALAN KAMPUS UNIVERSITAS MUHAMMADIYAH PURWOKERTO TAHUN 2017
}

\author{
Reko Indra Khoirurrozaq ${ }^{*}$, Asep Tata Guanawan ${ }^{* *}$ \\ Jurusan Kesehatan Lingkungan, Politeknik Kesehatan Kemenkes Semarang, \\ JL.Raya Baturraden KM 12 Purwokerto, Indonesia
}

Abstrak

Hygiene Sanitasi makanan seperti jumlah angka kuman adalah hal kebersihan yang sangat penting. Seperti cimol, cimol merupakan jajanan yang sangat di gemari banyak orang. Cimol yang tidak bersih dapat menyebabkan sakit perut maupun keracunan baik dari cara pengolahan, bahan makanan dan penjamah. Tujuan dari penelitian ini adalah untuk mengetahui angka kuman dan hygiene sanitasi yang terdapat pada pedagang cimol yang di jual di jalan kampus Universitas Muhammadiyah Purwokerto.Metode yang digunakan dalam penelitian ini adalah metode deskriptif. Pengumpulan data dilakukan melalui analisis laboratorium dengan metode Angka Lempeng Total ( ALT ) untuk menghitung angka kuman pada pedagang cimol yang di jual di jalan kampus Universitas Muhammadiyah Purwokerto. Hasil penelitian menunjukan bahwa angka kuman pada 8 sampel cimol. Pada sampel A adonan dan B adonan adalah 1,7 x $10^{2}$ koloni/gram dan $<1 \times 10^{1} \mathrm{koloni} /$ gram ; A1 dan B1 adalah 2,4 × $10^{1}$ koloni/gram dan 9,3 x $10^{1} \mathrm{koloni} / \mathrm{gram} ;$ A2 dan B2 adalah $<1 \times 10^{1} \mathrm{koloni} / \mathrm{gram}$ dan 2,3 x $10^{2}$ koloni/gram; A3 dan B3 adalah $<1 \times 10^{1} \mathrm{koloni} /$ gram dan $<1 \times 10^{1}$ koloni/gram. Disimpulkan penelitian menunjukan bahwa semua hasil dari pemeriksaan laboratorium menunjukan angka kuman yang berada di bawah batas maksimum cemaran mikroba dalam pangan yaitu 1 x $10^{4} \mathrm{Koloni} /$ gram. Akan tetapi dilihat dari sarana dan juga penjamah masih kurang. Disarankan kepada penjual untuk meningkatkan pengetahuan tentang hygiene sanitasi sarana dan penjamah untuk memberikan hasil yang sehat dan bersih dari cimol yang dijual. Serta juga mengurangi potensi cemaran kuman oleh paparan udara dilingkungan sekitar.

Kata Kunci: Hygiene, Sanitasi, Angka Kuman,Kesehatan Lingkungan

\begin{abstract}
[Study of sanitary hygiene and inspection numbers of germs on the seller cimol in Muhammadiyah University of Purwokerto in 2017] Hygiene of Food Sanitation as germ number amount is proper hygiene is very important. Like cimol, cimol is a very popular street food of many people. Unclean Cimol can cause stomach ache and poisoning either from processing, food and handlers. The purpose of this study is to determine the number of germs and sanitation hygiene contained in cimol traders who are sold on the campus road University of Muhammadiyah Purwokerto. The method used in this research is descriptive method. Data collection was done through laboratory analysis by Total Plate Number (ALT) method to calculate the number of germs on cimol traders sold on campus road of Muhammadiyah University of Purwokerto. The results showed that the number of germs in 8 samples cimol. In the sample A dough and B dough were $1.7 \times 10^{2}$ colonies / gram and $<1 \times 10^{1}$ colonies / grams; A1 and B1 are 2,4 $410^{1}$ colony / gram and 9,3 $\times 10^{1}$ colony / gram; $A 2$ and B2 are $<1 \times 10^{1}$ colonies / grams and 2,3 $\times 10^{2}$ colonies / grams; $A 3$ and $B 3$ are $<1 \times 10^{1}$ colonies / gram and $<1 \times 10^{1}$ colony / gram. The research concluded that all the results of laboratory examination showed the number of germs that are below the maximum limit of microbial contamination in food that is $1 \times 10^{4}$ Colonies / gram. However, seen from the facilities and also the handlers are still lacking. It is advisable to the seller to increase knowledge of sanitary hygiene facilities and handlers to deliver healthy and clean results from sold cimol. And also reduce the potential for contamination of germs by exposure to the environment.
\end{abstract}

Keywords: Hygiene, Sanitation, Germs, Environmental Health 


\section{Pendahuluan}

Pembangunan kesehatan adalah bagian dari pembangunan nasional yang bertujuan meningkatkan kesadaran, kemauan dan kemampuan hidup sehat bagi setiap orang agar terwujud derajat kesehatan masyarakat yang setinggi-tingginya. Pembangunan kesehatan tersebut merupakan upaya seluruh potensi bangsa Indonesia, baik masyarakat, swasta maupun pemerintah. Pembangunan dibidang kesehatan dapat dilaksanakan, melalui kegiatan antara lain perbaikan gizi, pengamanan makanan dan minuman dari bahan-bahan terlarang, kesehatan lingkungan dan lain-lain.

Makanan dan minuman yang memenuhi syarat kesehatan, perlu diadakan pengawasan terhadap hygiene dan sanitasi makanan dan minuman utamanya adalah usaha yang ditujukan untuk umum seperti restoran, rumah makan, ataupun pedagang kaki lima mengingat bahwa makanan dan mnuman merupakan media yang potensial dalam penyebaran penyakit. (Depkes RI, 2004)

Makanan dan minuman merupakan dua zat yang penting bagi kehidupan manusia. Makanan adalah zat yang dikonsumsi untuk memberikan dukungan nutrisi bagi tubuh. Makanan biasanya berasal dari tanaman, hewan, dan nutrisi penting seperti karbohidrat, lemak, protein, vitamin, dan mineral. Zat tersebut tertelan oleh organisme dan diasimilasi oleh organisme sel dalam upaya untuk menghasilkan energi, mempertahankan hidup, atau merangsang pertumbuhan. Sedangkan minuman merupakan zat cair atau cairan yang dibutuhkan oleh tubuh manusia.

Hygiene Sanitasi Makanan dan Minuman (HSMM) merupakan salah satu upaya dalam pengawasan makanan dan minuman yang berupaya untuk mencegah timbulnya bahaya penyakit akibat makanan dan minuman, serta untuk mencegah dan menghindari terjadinya penularan penyakit yang terdiri dari 6 prinsip pengolahan makanan. Upaya dibidang HSSM meliputi penyediaan bahan makanan, penyimpanan bahan makanan, pengolahan makanan, pengangkutan makanan, penyimpanan makanan dan penyajian makanan. HSMM dilakukan bertujuan agar makanan dan minuman yang dihasilkan kualitasnya terjaga dan aman untuk dikonsumsi. Cimol merupakan contoh makanan yang ditujukan untuk umum, sehingga cimol juga memerlukan pengawasan terhadap hygiene dan sanitasi makanan dan minuman. ( Anwar, 1998 )

Berdasarkan peraturan Badan Pengawasan Obat dan Makanan Republik Indonesia No. HK.00.06.1.52.4011 tanggal 28 Oktober 2009 tentang penetapan batas maksimum cemaran mikroba dan kimia dalam makanan untuk jenis olahan jenis tepung untuk

\footnotetext{
${ }^{*}$ E-mail: rekoindra26@gmail.com

${ }^{* *}$ E-mail: Aseptatagunawan@yahoo.co.id
}

dimakan bahwa Angka Lempeng Total ( ALT ) maksimumnya adalah 1 × $10^{4}$ Koloni/gram.

Jajanan di pinggir jalan memang menarik, murah dan rasanya yang enak tentu sudah diketahui memiliki kadar kehigienisan yang cenderung dibawah rata-rata. Jajanan pinggir jalan menyimpan berbagai bahaya tersendiri bagi kesehatan seperti makanan dibiarkan terbuka di udara bebas dalam waktu yang lama, kondisi jalanan yang jelas dipenuhi polusi udara dapat mempengaruhi kehigienisan dan kondisi makanan. Makanandisajikan dan dikonsumsi dalam suhu yang tidak layak, entah kurang panas atau kurang dingin, lalu kondisi makanan ini dapat menarik lalat yang membawa kuman.

Cimol adalah makanan ringan yang dibuat dari tepung kanji. Cimol berasal dari kata (Bahasa Sundaaci digemol), yang artinya tepung kanji dibuat bulat-bulat. Cimol banyak dijual di jalan kampus depan Universitas Muhammadiah Purwokerto, Kecamatan Kembaran, Kabupaten Banyumas. Para pedagang menjual dengan gerobag-gerobag. Jalan kampus Universitas Muhammadiah Purwokerto merupakan jalur yang banyak dilewati oleh alat transpotasi seperti mobil, motor, dan alat transpotasi yang lainnya.

Studi pendahuluan yang dilakukan oleh penulis di depan Universitas Muhammadiah Purwokerto dapat diketahui terdapat sebanyak 2 penjual. Jumlah pembeli disetiap penjual bervariasi, jika hari biasa dan waktu kuliah antara $30-50$ orang setiap harinya. Tetapi pada hari besar ataupun hari libur jumlah pembeli mencapai 20 - 40 orang. Ramainya jalan dan pembeli di penjual cimol tersebut memungkinkan kondisi hygiene dan sanitasi di makanan cimol tercemar kuman.

Berdasarkan latar belakang di atas, maka penulis tertarik untuk melakukan penelitian dengan judul "Studi Hygiene Sanitasi Dan Pemeriksaan Jumlah Angka Kuman Pada Penjual Cimol Di Jalan Kampus Universitas Muhammadiyah PurwokertoTahun 2017".

Tujuan penelitian ini untuk menghitung jumlah angka kuman pada makanan cimol yang di jual di jalan Kampus Universitas Muhammadiyah Purwokerto Tahun 2017

\section{Bahan dan Metode}

Jenis penelitian yang digunakan adalah penelitian deskriptif, menggambarkan tentang sanitasi dan jumlah angka kuman pada jajanan cimol yang dijual di Universitas Muhammadiyah Purwokerto Tahun 2017.

\section{Hasil dan Pembahasan}

Lokasi penelitian di Kecamatan Kembaran berada di wilayah utara kota adminstrasi Purwokerto. Kecamatan dengan luas wilayah $25,92 \mathrm{~km}^{2}$, terbagi menjadi 16 desa yang sebagian besar wilayahnya berupa hamparan. Desa Pliken merupakan desa dengan wilayah 
terluas dengan luas wilayah 3,4 km 2 atau sekira 13,1 persen dari luas wilayah Kecamatan Kembaran. Desa ini bahkan lebih luas dari penjumlahan luas wilayah tiga desa lain di Kecamatan Kembaran yaitu desa Sambeng Wetan, desa Purbadana dan desa Karangsoka. Berdasarkan data dari mantri tani Kecamatan Kembaran, tercatat 1771,184 ha dari luas kecamatan merupakan lahan pertanian berupa lahan irigasi teknis dan lahan irigasi setengah teknis.

Tabel 1. Batas Kecamatan Kembaran

\begin{tabular}{l|l}
\hline \multicolumn{2}{c}{ Batas Kecamatan Kembaran } \\
\hline Sebelah Utara & Kecamatan Sumbang \\
\hline Sebelah Timur & Kecamatan Purbalingga \\
\hline Sebelah Selatan & Kecamatan Sokaraja \\
\hline Sebelah Barat & $\begin{array}{l}\text { Kecamatan Purwokerto } \\
\text { Timur }\end{array}$ \\
\hline
\end{tabular}

Penelitian ini dilakukan di 2 pedagang cimol yang berjualan di jalan Kampus Universitas Muhammadiyah Purwokerto. Dimana daftar pedagang dapat dilihat di tabel 2 sebagai berikut :

Tabel 2. Sampel Pedagang

\begin{tabular}{ccl}
\hline No. & Kode Sampel & Pedagang \\
\hline 1. & A1 & 1 ( Pagi ) \\
2. & A2 & 1 ( Siang) \\
3. & A3 & 1 ( Sore ) \\
4. & Adonan A & 1 \\
5. & B1 & 2 ( Pagi ) \\
6. & B2 & 2 ( Siang) \\
7. & B3 & 2 ( Sore ) \\
8. & Adonan B & 2
\end{tabular}

Pengambilan Sampel Cimol dilakukan pada tanggal 3 Juli 2017 jam 09.00 WIB pada saat pedagang A berada di sebelah utara Apotek Universitas Muhammadiyah Purwokerto dan pedagang B berada di sebrang jalan, 13.00 WIB pada saat pedagang A berada di sebelah utara Apotek Universitas Muhammadiyah Purwokerto dan pedagang $B$ berada di sebrang jalan, dan 17.00 WIB pada saat pedagang A berada di depan Kantor Pusat Universitas Muhammadiyah Purwokerto dan pedagang B berada di sebelah barat dari pedagang A dengan jarak \pm 5 meter. Selanjutnya dapat dijelaskan di tabel 3 sebagai berikut :
Tabel 3. Pengambilan Sampel

\begin{tabular}{|l|l|l|l|l|}
\hline $\begin{array}{c}\text { Kode } \\
\text { Sampel }\end{array}$ & $\begin{array}{c}\text { Hari / } \\
\text { Tanggal } \\
\text { Peng- } \\
\text { ambilan } \\
\text { Sampel }\end{array}$ & $\begin{array}{c}\text { Waktu } \\
\text { Peng- } \\
\text { ambil } \\
\text { Sam- } \\
\text { pel }\end{array}$ & Lokasi & $\begin{array}{l}\text { Peng- } \\
\text { ambil } \\
\text { Sampel }\end{array}$ \\
\hline $\begin{array}{l}\text { A } \\
\text { Adonan }\end{array}$ & $\begin{array}{l}\text { Senin, 3 } \\
\text { Juli 2017 }\end{array}$ & $\begin{array}{l}09.00 \\
\text { WIB }\end{array}$ & $\begin{array}{l}\text { Lokasi } \\
\text { A }\end{array}$ & $\begin{array}{l}\text { Reko } \\
\text { Indra K }\end{array}$ \\
\hline A1 & $\begin{array}{l}\text { Senin, 3 } \\
\text { Juli 2017 }\end{array}$ & $\begin{array}{l}09.00 \\
\text { WIB }\end{array}$ & $\begin{array}{l}\text { Lokasi } \\
\text { A }\end{array}$ & $\begin{array}{l}\text { Reko } \\
\text { Indra K }\end{array}$ \\
\hline A2 & $\begin{array}{l}\text { Senin, 3 } \\
\text { Juli 2017 }\end{array}$ & $\begin{array}{l}13.00 \\
\text { WIB }\end{array}$ & $\begin{array}{l}\text { Lokasi } \\
\text { B }\end{array}$ & $\begin{array}{l}\text { Reko } \\
\text { Indra K }\end{array}$ \\
\hline A3 & $\begin{array}{l}\text { Senin, 3 } \\
\text { Juli 2017 }\end{array}$ & $\begin{array}{l}17.00 \\
\text { WIB }\end{array}$ & $\begin{array}{l}\text { Lokasi } \\
\text { C }\end{array}$ & $\begin{array}{l}\text { Reko } \\
\text { Indra K }\end{array}$ \\
\hline Adonan & $\begin{array}{l}\text { Senin, 3 } \\
\text { Juli 2017 }\end{array}$ & $\begin{array}{l}09.00 \\
\text { WIB }\end{array}$ & $\begin{array}{l}\text { Lokasi } \\
\text { A }\end{array}$ & $\begin{array}{l}\text { Reko } \\
\text { Indra K }\end{array}$ \\
\hline B1 & $\begin{array}{l}\text { Senin, 3 } \\
\text { Juli 2017 }\end{array}$ & $\begin{array}{l}09.00 \\
\text { WIB }\end{array}$ & $\begin{array}{l}\text { Lokasi } \\
\text { A }\end{array}$ & $\begin{array}{l}\text { Reko } \\
\text { Indra K }\end{array}$ \\
\hline B2 & $\begin{array}{l}\text { Senin, 3 } \\
\text { Juli 2017 }\end{array}$ & $\begin{array}{l}13.00 \\
\text { WIB }\end{array}$ & $\begin{array}{l}\text { Lokasi } \\
\text { B }\end{array}$ & $\begin{array}{l}\text { Reko } \\
\text { Indra K }\end{array}$ \\
\hline B3 & $\begin{array}{l}\text { Senin, 3 } \\
\text { Juli 2017 }\end{array}$ & $\begin{array}{l}17.00 \\
\text { WIB }\end{array}$ & $\begin{array}{l}\text { Lokasi } \\
\text { C }\end{array}$ & $\begin{array}{l}\text { Reko } \\
\text { Indra K }\end{array}$ \\
\hline
\end{tabular}

Menurut Keputusan Menteri Kesehatan RI Nomor 942/ MENKES/ SK/ VII/2003 tentang pedoman persyaratan hygiene sanitasi makanan jajanan yang dimaksud hygiene sanitasi adalah upaya untuk mengendalikan, salah satunya faktor bahan makanan yaitu tepung aci. Menurut Standar Nasional Indonesia (SNI) nomor 3451-1994 Tepung tapioka yang baik tidak bergumpal, tidak berubah warna diawali bintik-bintik noda / bercak, tidak berbau apek dan asam. Berdasarkan tabel 4 kondisi tepung 2 pedagang cimol tersebut memenuhi syarat karena sesuai kondisi tepung tidak bergumpal, tidak berubah warna diawali bintik-bintik noda / bercak, tidak berbau apek dan asam.

Tabel 4. Tepung Aci

$\begin{array}{ccc} & \text { Kode } & \text { Tepung Aci Memenuhi Syarat } \\ \text { No. } & \text { Sampel } & \text { (MS)/ Tidak Memenuhi Syarat } \\ & & \text { (TMS) }\end{array}$

$\begin{array}{lll}1 . & \text { A } & \text { MS } \\ 2 . & \text { B } & \text { MS }\end{array}$

Menurut Keputusan Menteri Kesehatan RI Nomor 942/MENKES/SK/VII/2003 tentang Pedoman Persyaratan Hygiene Sanitasi Makanan Jajanan yaitu 
peralatan yang digunakan untuk mengolah dan menyajikan jajanan makanan harus sesuai dengan peruntukannya dan memenuhi persyaratan hygiene sanitasi, peralatan yang sudah dipakai dicuci dengan air bersih dan dengan sabun, lalu dikeringkan dengan alat pengering / lap yang bersih, kemudian peralatan yang sudah bersih tersebut disimpan di tempat yang bebas pencemaran, dilarang menggunakan kembali peralatan yang dirancang hanya untuk sekali pakai.

Berdasarkan tabel 5 dikategorikan bahwa sanitasi peralatan pada 2 pedagang cimol di Jalan Kampus Universitas Muhammadiyah Purwokerto Tahun 2017 tidak memenuhi syarat semua. Adapun hal yang tidak memenuhi syarat adalah peralatan berada di tempat terbuka. Karena penjamah biasanya membiarkan peralatan terpapar oleh udara yg tercampur debu dan asap kendaran, selain itu penjamah lebih sering membersihkan tangan yang kotor dengan lap yang sudah di pakai berkali-kali dalam kondisi tidak layak pakai.

Tabel 5. Sanitasi Peralatan

\begin{tabular}{ccc} 
No. & $\begin{array}{c}\text { Kode } \\
\text { Sampel }\end{array}$ & $\begin{array}{c}\text { Peralatan Memenuhi Syarat (MS) / } \\
\text { Tidak Memenuhi Syarat (TMS) }\end{array}$ \\
\hline 1. & A & TMS \\
2. & B & TMS
\end{tabular}

Sedangkan untuk perlengkapan pemrosesan makanan, Berdasarkan tabel 6 perlengkapan pemrosesan makanan dihasilkan 2 pedagang cimol memenuhi syarat. Adapun hal yang memenuhi syarat adalah bahan antikarat, kedap air, halus, mudah dibersihkan, tidak mudah berubah warna dan berasa, peralatan bahan kayu tidak boleh kontak langsung dengan makanan, plastik aman dan mudah digunakan. Kondisi perlengkapan pemrosesan makanan yang baik akan memperkecil potensi tercemarnya makanan oleh bakteri dan kuman.

Tabel 6. Pemrosesan Makanan

\begin{tabular}{ccc}
\hline No. & $\begin{array}{c}\text { Kode } \\
\text { Sampel }\end{array}$ & $\begin{array}{r}\text { Perlengkapan Pemrosesan Makanan } \\
\text { Memenuhi Syarat (MS) / Tidak } \\
\text { Memenuhi Syarat (TMS) }\end{array}$ \\
\hline 1. & A & MS \\
2. & B & MS
\end{tabular}

Pada penelitian ini penjamah makanan adalah orang yang memilih bahan hingga proses penyajian makanan. Penjamah dapat menjadi sumber tercemarnya cimol tersebut. Menurut Keputusan Menteri Kesehatan RI Nomor 942/MENKES/SK/VII/2003 tentang hygiene sanitasi penjamah makanan yaitu penjamah makanan jajanan dalam melakukan kegiatan pelayanan penanganan makanan jajanan harus memenuhi persyaratan meliputi tidak menderita penyakit mudah menular (batuk, pilek, influenza, diare, penyakit perut sejenisnya), Menutup luka (pada luka terbuka/ bisul atau lainnya), menjaga kebersihan tangan, rambut, kuku, dan pakaian, memakai celemek dan penutu kepala, mencuci tangan setiap kali hendak menangani makanan, menjamah makanan harus menggunakan alat/perlengkapan atau dengan alas tangan, tidak sambil merokok, tidak menggaruk anggota badan (telinga, hidung, mulut, atau bagian lainnya), tidak batuk atau bersin dihadapan makanan jajanan yang disajikan dan atau tanpa penutup mulutu atau hidung.

Berdasarkan tabel7 Personal Hygiene bahwa 2 pedagang cimol tidak memenuhi syarat. Adapun hal yang tidak memenuhi syarat adalah tidak memakai celemek dan tidak memakai alas tangan (Sarung Tangan). Seharusnya penjamah lebih memperhatikan personal hygiene dengan benar, sehingga dapat mencegah terjadinya kecelakaan kerja seperti terkena wajan atau teflon yang panas dan terciprat minyak goreng saat mengolah makanan, serta juga harus memakai sarung tangan karena apabila tidak menggunakan sarung tangan akan membahayakan diri sendiri dan berpotensi terjainya kontaminasi makanan. Jika tidak menggunakan sarung tangan upayakan mencuci tangan sesudah dan sebelum mengolah makanan, sehingga tangan tetap bersih dan mencegah terjadinya kontaminasi makanan.

Tabel 7. Personal Hygiene

\begin{tabular}{ccc}
\hline No. & $\begin{array}{c}\text { Kode } \\
\text { Sampel }\end{array}$ & $\begin{array}{c}\text { Personal Hygiene Memenuhi } \\
\text { Syarat (MS) / Tidak Memenuhi } \\
\text { Syarat (TMS) }\end{array}$ \\
\hline 1. & A & TMS \\
2. & B & TMS \\
\hline
\end{tabular}

Berdasarkan tabel 8 Perilaku Penjamah bahwa 1 pedagang memenuhi syarat. Adapun hal yang memenuhi syarat adalah tidak sambil merokok, tidak sambil menggaruk anggota badan dan tidak batuk atau bersin dihadapan makanan. Sedangkan 1 pedagang tidak memenuhi syarat. Adapun hal yang tidak memenuhi syarat adalah sambil merokok. Penjamah harus memperhatikan perilaku pada saat melakukan kegiatan memasak agar tidak terjadi kontaminasi makanan. Rokok memiliki banyak sekali zat-zat berbahaya didalamnya maka sebaiknya tidak merokok pada saat memasak. 
Tabel 8. Penjamah Makanan

\begin{tabular}{ccc}
\hline No. & $\begin{array}{c}\text { Kode } \\
\text { Sampel }\end{array}$ & $\begin{array}{c}\text { Perilaku Penjamah Memenuhi Syarat } \\
\text { (MS) / Tidak Memenuhi Syarat } \\
\text { (TMS) }\end{array}$ \\
\hline 1. & A & TMS \\
2. & B & MS \\
\hline
\end{tabular}

Berdasarkan tabel 9 hygiene sanitasi tempat bahwa 2 pedagang cimol tidak memenuhi syarat. Adapun hal yang memenuhi syarat adalah tempat berjualan tertutup, mudah di bersihkan, tersedia tempat air, tersedia tempat penyimpanan bahan makanan, tersedia tempat penyimpanan alat, tersedia tempat pencuci tangan, tersedia tempat cuci alat, dan tersedia tempat sampah. Adapun hal yang tidak memenuhi syarat adalah tempat berjualan terlalu terbuka. Jika tempat berjualan tidak tertutup dan melindungi makanan dari pencemaran maka potensi terkontaminasi makanan tersebut akan besar dan juga dikarenakan lokasi berjualan berada di pinggir jalan raya, banyak sekali aktifitas kendaraan yang lewat.

Tabel 9. Hygiene Sanitasi Tempat

\begin{tabular}{ccc}
\hline No. & $\begin{array}{c}\text { Kode } \\
\text { Sampel }\end{array}$ & $\begin{array}{c}\text { Sanitasi tempat Memenuhi Syarat } \\
\text { (MS)/ Tidak Memenuhi Syarat } \\
\text { (TMS) }\end{array}$ \\
\hline 1. & A & TMS \\
2. & B & TMS
\end{tabular}

Tepung tapioka atau juga sering di sebut tepung kanji atau tepung aci adalah tepung yang bahan bakunya $100 \%$ terbuat dari singkong atau ubi kayu. Menurut Standar Nasional Indonesia (SNI) nomor 3451-1994 Tepung tapioka yang baik tidak terdapat kutu, tidak berbau apek dan asam dan tidak berubah warna. Untuk batas minimum cemaran mikroba dan kimia dalam makanan untuk jenis olahan jenis tepung untuk dimakan bahwa Angka Lempeng Total (ALT) maksimumnya adalah $1 \times 10^{4}$ Koloni/gram.Berdasarkan table 10 Pemilihan Bahan Baku bahwa Tepung pada 2 penjual cimol di jalan Kampus Universitas Muhammadiyah Purwokerto memenuhi syarat. Adapun hal yang memenuhi syarat adalah tidak berbau apek, tidak terdapat kutu, tidak ada perubahan warna.

Tabel 10. Pemilihan Bahan Baku

\begin{tabular}{ccc}
\hline No. & $\begin{array}{c}\text { Kode } \\
\text { Sampel }\end{array}$ & $\begin{array}{c}\text { Sanitasi tempat Memenuhi Syarat } \\
\text { (MS) / Tidak Memenuhi Syarat } \\
\text { (TMS) }\end{array}$ \\
\hline 1. & A & MS \\
2. & B & MS \\
\hline
\end{tabular}

Menurut Permenkes 712/Menkes/PER/10/86, bahwa : Bahan makanan yang sangat penting dalam penyimpanannya. Faktor yang sangat berpengaruh adalah "suhu", dan "kelembaban", sehingga dalam penyimpanan bahan makanan harus memperhatikan beberapa faktor yaitu suhu penyimpanan 3 hari/kurang $25^{\circ} \mathrm{C}$, suhu penyimpanan $1 \mathrm{minggu} /$ kurang $25^{\circ} \mathrm{C}$, suhu penyimpanan 1 minggu $25^{\circ} \mathrm{C}$. Berdasarkan tabel 11 Penyimpanan Tepung Aci bahwa 2 pedagang cimol memenuhi syarat. Adapun hal yang memenuhi syarat adalah suhu penyimpanan 3 hari / kurang $25^{\circ} \mathrm{C}$, suhu penyimpanan 1 minggu / kurang $25^{\circ} \mathrm{C}$, dan suhu penyimpanan 1 minggu $25^{\circ} \mathrm{C}$. Karena kualitas tepung akan baik jika sesuai dengan suhu yang semestinya.

Tabel 11. Penyimpanan Tepung

\begin{tabular}{ccc}
\hline No. & $\begin{array}{c}\text { Kode } \\
\text { Sampel }\end{array}$ & $\begin{array}{c}\text { Penyimpanan Tepung Aci Memenuhi } \\
\text { Syarat (MS) / Tidak Memenuhi } \\
\text { Syarat (TMS) }\end{array}$ \\
\hline 1. & A & MS \\
2. & B & MS \\
\hline
\end{tabular}

Berdasarkan tabel 12 Peracikan Bahan Cimol bahwa 2 pedagang cimol memenuhi syarat. Adapun hal yang memenuhi syarat adalah memasukan tepung dalam wadah, masukan baking soda dan bahan lainnya, aduk merata bahan. Sebaiknya penjamah sebelum melakukan proses peracikan lebih baik melakukan cuci tangan terlebih dahulu dan memakai alat-alat seperti sarung tangan untuk menghindari kontaminasi pada bahan cimol tersebut. Selain itu untuk kebersihan wadah juga harus dalam keadaan bersih.

Tabel 12. Peracikan Bahan Cimol

$\begin{array}{ccc}\text { No. } & \text { Kode } & \text { Peracikan Bahan Cimol Memenuhi } \\ & \text { Sampel } & \text { Syarat (MS) / Tidak Memenuhi } \\ & & \text { Syarat (TMS) }\end{array}$

\begin{tabular}{lll}
1. & A & MS \\
2. & B & MS \\
\hline
\end{tabular}

Berdasarkan table 13 Cara memasak bahwa 2 pedagang memenuhi syarat. Adapun hal yang memenuhi syarat adalah masukan minyak goreng, goreng dengan suhu $\pm 70^{\circ} \mathrm{C}$, membentuk adonan menjadi bulatan kecil, masukan adonan cimol, taburkan bahan tambahan ( asin, pedas). Pada saat memasak penjamah seharusnya memakai celemek untuk menghindari cipertan minyak dari wajan dan juga cimol harus dibuat menjadi bulatan kecil sesuai cimol pada umumnya. 
Tabel 13. Cara Memasak

\begin{tabular}{ccc} 
No. & $\begin{array}{c}\text { Kode } \\
\text { Sampel }\end{array}$ & $\begin{array}{c}\text { Pemasakan / penggorengan } \\
\text { Memenuhi Syarat (MS) / Tidak } \\
\text { Memenuhi Syarat (TMS) }\end{array}$ \\
\hline 1. & A & MS \\
2. & B & MS \\
\hline
\end{tabular}

Persyaratan penyajian makanan menurut Keputusan Menteri Kesehatan RI Nomor 942/MENKES/SK/VII/2003 tentang Pedoman Persyaratan Hygiene Sanitasi Makanan Jajanan, makanan jajanan harus disajikan sebagai berikut yaitu Makanan jajanan yang disajikan harus dengan tempat/alat perlengkapan yang bersih, dan aman bagi kesehatan, Makanan jajanan yang dijajakan harus dalam keadaan terbungkus dan atau tertutup, Pembungkus yang digunakanan dan atau tutup makanan jajanan harus dalam keadaan bersih dan tidak mencemari makanan, pembungkus dilarang ditiup.Berdasarkan table 14 bahwa 2 pedagang tidak memenuhi syarat. Adapun hal yang memenuhi syarat adalah tempat/alat perlengkapan yang bersih, dan aman bagi kesehatan, Makanan jajanan yang dijajakan harus dalam keadaan terbungkus dan atau tertutup, Pembungkus yang digunakanan dan atau tutup makanan jajanan harus dalam keadaan bersih dan tidak mencemari makanan, pembungkus dilarang ditiup. Adapun hal yang tidak memenuhi syarat adalah makanan / jajanan tidak dalam kondisi tertutup / terbungkus. Makanan yang tidak tertutup akan mudah terkena kontaminasi, apalagi lokasi penjualan cimol berada di jalan raya yang banyak sekali kendaran yang lewat. Kondisi tidak tertutup ini berasal dari tempat berjualan cimol tersebut / gerobag cimol yang terlalu terbuka.

Tabel 14. Penyajian Makanan

$\begin{array}{ccc}\text { No. } & \text { Kode } & \text { Penyajian Makanan Memenuhi } \\ & \text { Sampel } & \text { Syarat (MS) / Tidak Memenuhi } \\ & \text { Syarat (TMS) }\end{array}$

$\begin{array}{lll}\text { 1. } & \text { A } & \text { TMS } \\ \text { 2. } & \text { B } & \text { TMS }\end{array}$

Pengambilan sampel dilakukan pada 3 waktu berbeda yaitu pada jam 09.00 WIB pada saat pedagang A berada di sebelah utara Apotek Universitas Muhammadiyah Purwokerto dan pedagang B berada di sebrang jalan, 13.00 WIB pada saat pedagang A berada di sebelah utara Apotek Universitas Muhammadiyah Purwokerto dan pedagang B berada di sebrang jalan, dan 17.00 WIB pada saat pedagang A berada di depan Kantor Pusat Universitas Muhammadiyah Purwokerto dan pedagang $\mathrm{B}$ berada di sebelah barat dari pedagang A dengan jarak \pm 5 meter, pada tanggal 3 juli 2017. Sampel A adonan, B adonan, A1, dan B1 di ambil jam 09.00 WIB. Sampel A2 dan B2 di ambil jam 13.00 WIB. Sampel A3 dan B3 di ambil jam 17.00 WIB.

Hasil pemeriksaan cimol yang dijual di Jalan kampus Universitas Muhammadiyah Purwokerto yang dilakukan di Laboratorium Kesehatan Masyarakat Kabupaten Banyumas yaitu sampel A adonan, B adonan, A1, A2, A3, B1, B2, B3 negatif (-) / memenuhi syarat. Menurut Badan Standarisasi Nasional SNI 7388 : 2009 batas maksimum cemaran mikroba dalam pangan / pada makanan siap santap yaitu 1 x $10^{4}$ koloni/gram. Untuk sampel A adonan, B adonan, A1, A2, A3, B1, B2, B3 hasilnya berada dibawah batas maksimum cemaran mikroba dalam pangan. Pemeriksaan ini menggunakan metode Aangka Lempeng Total ( ALT ).

Tabel 15. Angka Kuman

\begin{tabular}{lccc}
\hline $\begin{array}{c}\text { Kode } \\
\text { Sampel }\end{array}$ & $\begin{array}{c}\text { Hasil } \\
\text { Pemeriksa- } \\
\text { an }\end{array}$ & $\begin{array}{c}\text { Standart } \\
\text { (Batas } \\
\text { Maksimum) }\end{array}$ & Keterangan \\
\hline $\begin{array}{l}\text { A } \\
\text { Adonan }\end{array}$ & $1,7 \times 10^{2}$ & & MS \\
A2 & $2,4 \times 10^{1}$ & MS \\
A3 & $<1 \times 10^{1}$ & MS \\
B & $<1 \times 10^{1}$ & Koloni/gram & MS \\
Adonan & $<1 \times 10^{1}$ & & MS \\
B1 & $9,3 \times 10^{1}$ & & MS \\
B2 & $2,3 \times 10^{2}$ & & MS \\
B3 & $<1 \times 10^{1}$ & & MS \\
\hline
\end{tabular}

Dari hasil pemeriksaan yang telah dilakukan oleh peneliti di 2 pedagang cimol yang dijual di jalan Kampus Universitas Muhammadiyah Purwokerto dapat diambil kesimpulan sebagai berikut :

1. Hygiene Sanitasi Pengolahan Cimol

a. Bahan Makanan

Berdasarkan hasil observasi yang dilakukan oleh peneliti pada dua pedagang cimol dari aspek bahan makanan ditemukan hasil memenuhi syarat semua.

b. Peralatan

1) Sanitasi Peralatan

Berdasarkan hasil observasi yang dilakukan oleh peneliti pada dua pedagang cimol dari aspek sanitasi peralatan ditemukan hasil tidak memenuhi syarat. Adapun terdapat salah satu komponen yang tidak memenuhi syarat yaitu peralatan tidak disimpan di tempat yang bebas dari pencemaran. 
2) Perlengkapan Pemrosesan Makanan

Berdasarkan hasil observasi yang dilakukan oleh peneliti pada dua pedagang cimol dari aspek perlengkapan pemrosesan makanan ditemukan hasil memenuhi syarat semua.

c. Penjamah

1) Personal Hygiene

Berdasarkan hasil observasi yang dilakukan oleh peneliti pada dua pedagang cimol dari aspek personal hygiene ditemukan hasil tidak memenuhi syarat semua. Komponen yang menyebabkan tidak memenuhi syarat yaitu tidak memakai celemek dan tidak memakai alas tangan ( sarung tangan ).

2) Perilaku Penjamah

Berdasarkan hasil observasi yang dilakukan oleh peneliti pada dua pedagang cimol dari aspek perilaku penjamah dikategorikan satu pedagang memenuhi syarat dan satu pedagang dikategorikan tidak memenuhi syarat. Komponen yang menyebabkan tidak memenuhi syarat yaitu penjamah melakukan kegiatan sambil merokok.

d. Sanitasi Tempat

Berdasarkan hasil observasi yang dilakukan oleh peneliti pada dua pedagang cimol dari aspek sanitasi tempat ditemukan hasil tidak memenuhi syarat semua. Komponen yang menyebabkan tidak memenuhi syarat yaitu tempat berjualan / konstruksinya tidak melindungi makanan dari pencemaran.

e. Penyimpanan Tepung

Berdasarkan hasil observasi yang dilakukan oleh peneliti pada dua pedagang cimol dari aspek penyimpanan tepung ditemukan hasil memenuhi syarat semua.

f. Pengolahan Tepung

1) Peracikan Bahan Cimol

Berdasarkan hasil observasi yang dilakukan oleh peneliti pada dua pedagang cimol dari aspek peracikan bahan cimol ditemukan hasil memenuhi syarat semua.

2) Pemasakan / Penggorengan

Berdasarkan hasil observasi yang dilakukan oleh peneliti pada dua pedagang cimol dari aspek pemasakan / penggorengan ditemukan hasil memenuhi syarat semua.

g. Penyajian Makanan

Berdasarkan hasil observasi yang dilakukan oleh peneliti pada dua pedagang cimol dari aspek penyajian makanan ditemukan hasil tidak memenuhi syarat semua. Komponen yang menyebabkan tidak memenuhi syarat yaitu makanan / jajanan tidak dalam kondisi tertutup / terbungkus.
2. Jumlah Angka Kuman

Hasil pemeriksaan pada dua pedagang cimol yang dijual di Jalan Kampus Universitas Muhammadiyah Purwokerto sebagai berikut :

a. Sampel adonan dari dua pedagang memenuhi syarat dengan hasil jumlah angka kumannya yaitu $1,7 \times 10^{2}$ dan $<1 \times 10^{1}$ yang berarti masih dibawah batas maksimum cemaran mikroba dalam pangan menurut Badan Standarisasi Nasional.

b. Sampel A1 dan B1 dari dua pedagang yang diambil pada jam 09.00 WIB memenuhi syarat dengan hasil jumlah angka kumannya yaitu 2,4 x $10^{1}$ dan $9,3 \times 10^{1}$ yang berarti masih dibawah batas maksimumcemaran mikroba dalam pangan menurut Badan Standarisasi Nasional. Tetapi pada sampel yang di ambil jam 09.00 WIB tersebut memiliki hasil paling tinggi dari sampel yang di ambil pada jam yang berbeda.

c. Sampel A2 dan B2 pedagang yang diambil pada jam 13.00 WIB memenuhi syarat dengan hasil jumlah angka kumannya yaitu $<1 \times 10^{1}$ dan 2,3 $\times 10^{2}$ yang berarti masih dibawah batas maksimum cemaran mikroba dalam pangan menurut Badan Standarisasi Nasional.

d. Sampel A3 dan B3 pedagang yang diambil pada jam 17.00 WIB memenuhi syarat dengan hasil jumlah angka kumannya yaitu $<1 \times 10^{1}$ dan $<1 \times 10^{1}$ yang berarti masih dibawah batas maksimum cemaran mikroba dalam pangan menurut Badan Standarisasi Nasional.

\section{Ucapan Terima Kasih}

Peneliti mengucapkan banyak terimakasih kepada pihak pedagang cimol yang telah memberikan ijin penelitian jumlah angka kuman pada cimol serta seluruh pihak yang membantu terselesainya penelitian ini.

\section{Daftar Pustaka}

Anwar, dkk. 1998, Sanitasi Makanan dan Minuman pada Institusi PendidikanTenaga Sanitasi Cet. 4, Departemen Kesehatan Republik Indonesia

Catur Indah Oktaliasari. 2009. Studi Tentang Hygiene Sanitasi Pembutan danKualitas Mikrobiologis Jenang Salak di Desa Bantarwaru Kecamatan MadukaraKabupaten Banjarnegara tahun 2009. Politeknik Kesehatan Semarang JurusanKesehatan Lingkungan Purwokerto.

Direktorat Jenderal Pengendalian Penyakit dan Penyehatan Lingkungan, 2011,Bahan Makanan dibagi 3 Golongan Besar, Departemen Kesehatan RepublikIndonesia

(http://budaya-indonesia.org/Cimol/) 
(http://www.kerjanya.net/faq/18470-soda-kue.html)

(https://meetdoctor.com/mobile/article/bahaya-jajananpinggir-jalan-1)

(http://www.organisasi.org/1970/01/definisi-pengertiankuman-penyebab-penyakitdan-gangguankesehatan.html)

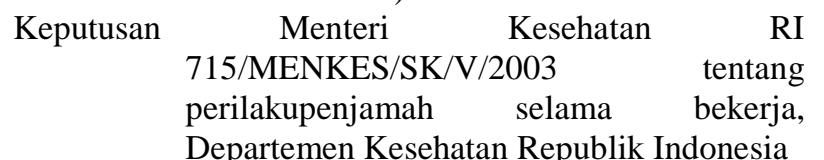

Keputusan Menteri Kesehatan RI No. 942/MENKES/SK/VII/2003 tentang pedomanpersyaratan Hygiene Sanitasi Makanan Jajanan, Departemen KesehatanRepublik Indonesia

Peraturan Badan Pengawas Obat dan Makanan RI No. HK.00.06.1.52.4011 tanggal28 Oktober 2009 tentang penetapan batas maksimum cemaran mikroba dankimia dalam makanan untuk jenis oalahan jenis tepung
Peraturan Menteri Kesehatan RI No. 1096/MENKES/PER/VI/2011 tentang HygieneSanitasi jasa boga

Peraturan Menteri Kesehatan RI 712/Menkes/PER/10/86 tentang Penyimpananbahan makanan

Soebagio Reksosoebroto. 1978. Hygiene dan Sanitasi. Jakarta : Akademi PenilikKesehatan Teknologi Sanitasi

Standar Nasional Indonesia (SNI) nomor 3594 - 2009 Tentang Tepung Beras

Standar Nasional Indonesia (SNI) nomor 7338 : 2009 Batas Maksimum Mikroba Dalam Pangan 